\title{
PJJ Menggunakan Model Project Based Learning dengan Kolaborasi 11 Mata Pelajaran Untuk Meningkatkan Pemahaman Siswa Terhadap Wabah Covid 19 di Kelas 8A SMPN 4 Cikalongwetan \\ Endang Wahyu Widiasari
}

SMPN 4 Cikalongwetan

diankhoirulhuda.ggd@gmail.com

Article History

accepted 01/12/2020

approved 01/01/2021

published 01/03/2021

\begin{abstract}
To succeed in 21st century learning, especially during the Covid-19 pandemic, teachers need to design a meaningful distance learning process. It can be an effort so that students don't get bored and can learn well even during the Covid-19 pandemic. Distance learning was very complicated and ineffective happened in this school. However, as educators we are required to continue to innovate and improve distance learning activities as well as provide learning services and explore the students' potential. Based on the problems, we tried to find a way out by observing in the field. We decided to carry out learning activities in collaboration with teachers of other subjects, also with parents of students. The learning model was Project-Based Learning by involving all subjects into in a theme of "Freedom from Covid-19" to increase understanding of both students and parents about the Covid-19 pandemic outbreak. From the results of the learning activities carried out, it can be concluded that distance learning with the Project-Based Learning model and collaboration of 11 subjects and also working with parents in class 8 of SMP Negeri 4 Cikalongwetan, which the theme of "Freedom from Covid-19", could improve students' understanding of the Covid-19 outbreak. Besides, it also accelerated the delivery of messages about the dangers of the Covid-19 outbreak to students and their parents. Keywords: PJBL, Collaboration, Covid-19 Outbreak
\end{abstract}

\begin{abstract}
Abstrak
Untuk mensukseskan pembelajaran abad 21, apalagi di era Covid 19, maka guru perlu merancang proses pembelajaran jarak jauh yang bermakna. Sebagai upaya agar siswa tidak bosan, dan tetap bisa belajar walaupun di tengah pandemi covid 19, yang entah sampai kapan akan berakhir. Selama ini yang penulis rasakan pembelajaran jarak jauh sangat ribet dan tidak efektif, begitu juga yang dikeluhkan oleh teman-teman semuanya di sekolah. Namun apapun alasannya sebagai pendidik kita dituntut untuk terus berinovasi memperbaiki kegiatan PJJ, untuk memberikan pelayanan pembelajaran dan menggali potensi siswa. Dari masalah yang dihadapi, maka kami mencoba mencari jalan keluar dengan cara bereksperimen di lapangan, melakukan kegiatan pembelajaran dengan berkolaborasi dengan guru mata pelajaran yang lainnya, juga dengan orang tua siswa, adapun model pembelajaran yang diambil adalah Project Based Learning dengan melibatkan semua mata pelajaran menjadi satu kesatuan dalam tema Merdeka dari Covid 19 untuk meningkatkan pemahaman baik siswa ataupun orang tua siswa terhadap wabah pandemi covid 19. Dari hasil kegiatan yang dilakukan, dapat diambil kesimpulan bahwa pembelajaran jarak jauh dengan menggunakan model pembelajaran Project Based Learning dengan kolaborai 11 mata pelajaran dan juga bekersama dengan orang tua siswa di kelas 8 SMP Negeri 4 Cikalongwetan, yang mengangkat tema Merdeka dari covid 19, dapat meningkatkan pemahaman siswa terhadap wabah covid 19, selain itu juga mempercepat penyampaian pesan akan bahaya wabah covid 19 kepada siswa dan juga orang tua siswa

Kata kunci: PjBL, Kolaborasi, Wabah Covid 19
\end{abstract}

Social, Humanities, and Education Studies (SHEs): Conference Series https://jurnal.uns.ac.id/shes

p-ISSN 2620-9284

e-ISSN 2620-9292

This work is licensed under a Creative Commons Attribution-ShareAlike 4.0 International License. 


\section{PENDAHULUAN}

Untuk mensukseskan pembelajaran abad 21, apalagi di era Covid 19, maka guru perlu merancang proses pembelajaran jarak jauh yang menyenangkan. Sebagai upaya agar siswa tidak bosan, dan tetap bisa belajar walaupun di tengah pandemi covid 19, yang entah sampai kapan akan berakhir. Selama ini yang penulis rasakan pembelajaran jarak jauh sangat ribet dan tidak efektif, begitu juga yang dikeluhkan oleh teman-teman semuanya di sekolah. Namun apapun alasannya sebagai pendidik kita dituntut untuk terus berinovasi memperbaiki kegiatan PJJ, untuk memberikan pelayanan pembelajaran dan menggali potensi siswa.

Siswa terlihat tidak semangat dalam kegiatan pembelajaran. Mengajar secara daring memang terasa melelahkan dan menbosankan. Orang tua merasa kewalahan karena harus mengajar anaknya di rumah, sementara banyak tugas sebagai lbu rumah tangga yang harus dikerjakan, siswapun tak paham dengan kegiatan pembelajaran jarak jauh. Virus yang semakin masiv penyebarannya, membuat semua pihak kewalahan. Tak heran beberapa waktu lalu dikabarkan, ada orang tua yang tega membunuh anaknya, dan yang menjadi penyebabnya adalah karena kegiatan pembelajaran jarak jauh yang dirasa sangat menjenuhkan.

Dari hari ke hari kegiatan pembelajaran jarak jauh sangat menjenuhkan dan melelahkan. Hal ini dirasakan baik oleh penulis sendiri ataupun teman-teman lain khususnya di SMPN 4 Cikalongwetan. Banyak kendala yang dihadapi dilapangan, seperti guru tidak bertatap muka langsung dengan siswa, apalagi ditambah dengan sarana komunikasi yang terbatas, jaringan internet yang sulit terkoneksi, dan keterbatasan kepemilikan kuota. Semua ini mempersulit kegiatan pembelajaran Jarak Jauh terlaksana. Semua yang dialami menyebabkan banyak guru dan siswa, serta orang tua siswa menjadi stres dalam melaksanakan kegiatan pembelajaran jarak jauh ini.

Masalah-masalah di atas berdampak kepada capaian hasil belajar siswa, meskipun selama pandemi covid 19 tidak diharuskan menargetkan target capaian kurikulum. Akan tetapi proses kegiatan harus terus berjalan, agar siswa dapat mengembangkan kreativitas dan juga potensinya di tengah pandemi covid 19 ini.

Kondisi seperti ini tidak boleh dibiarkan berlarut larut, harus dicarikan solusi dari permasalahan yang sedang dihadapi, bagaimanapun siswa harus mendapatkan hak nya, menerima pendidikan selama pandemi covid 19, walau dilaksanakan secara daring. Untuk itu komunikasi yang instensif antara pihak sekolah dan orang tua sangat diperlukan, agar hal-hal yang tidak diinginkan tidak terjadi. Jangan sampai terjadi kesalahan dalam menerima informasi, dan saling menyalahkan antara orang tua siswa dan guru dalam kegiatan pembelajaran jarak jauh ini, hingga akhirnya siswa yang menjadi korban.

Setelah dianalisis, ada beberapa kemungkinan mengapa selama ini pembelajaran jarak jauh dirasakan menjenuhkan dan membosankan, baik bagi siswa, guru ataupun orang tua siswa khususnya di SMPN 4 Cikalongwetan, diantaranya :

1. Tidak terjalin komunikasi yang harmonis, antara orang tua dengan guru untuk keberlangsungan kegiatan pembelajaran jarak jauh ini.

2. Guru kurang berinovasi dalam melaksanakan kegiatan pembelajaran jarak jauh.

3. Tidak ada kerjasama / kolaborasi antara guru mata pelajaran yang satu dengan guru mata pelajaran yang lainya

4. Pembelajaran tidak mengkaitkan dengan kondisi yang terjadi sekarang ini.

5. Selama ini setiap tugas yang dibenbankan kepada siswa cenderung menjadi beban yang memberatkan bagi siswa dan lebih banyak memekankan aspek kognitif.

6. Selain lebih banyak menekankan aspek kognitif dalam pemberian tugas kepada siswa, guru juga berjalan sendiri-sendiri dalam kegiatan pembelajaran, tidak 
melakukan kegiatan kolaborasi dalam kegiatan pembelajaran, hal ini memberatkan siswa dalam mengerjakan tugas yang diberikan.

Dari masalah yang dihadapi, maka kami mencoba mencari jalan keluar dengan cara bereksperimen di lapangan, melakukan kegiatan pembelajaran dengan berkolaborasi dengan guru mata pelajaran yang lainnya, juga dengan orang tua siswa, adapun model pembelajaran yang diambil adalah Project Based Learning dengan melibatkan semua mata pelajaran menjadi satu kesatuan dalam tema Merdeka dari Covid 19 untuk meningkatkan pemahaman baik siswa ataupun orang tua siswa terhadap wabah pandemi covid 19.

\section{HASIL DAN PEMBAHASAN}

Jalan keluar untuk permasalahan di SMPN 4 Cikalongwetan sebagai berikut

1. Memperbaiki kegiatan mengajar belajar selama covid 19, dengan pembelajaran yang bermakna, seperti yang di anjurkan oleh Mas Mentri yaitu dengan menggunakan model Project Based Learning. Dengan mengkolaborasikan beberapa mata pelajaran ke dalam satu tema yaitu Merdeka dari covid 19.

2. Memberikan pengarahan kepada siswa melalui kegiatan pembelajaran tentang wabah covid 19, dengan melibatkan semua mata pelajaran.

3. Melakukan kerjasama dengan orang tua siswa.

Setelah berembuk dengan semua dewan guru kami mencoba model Project Based Learning dengan pendekatan STEM akan tetapi dengan mengkolaborasikan semua mapel kedalam satu tema dengan tujuan untuk mempermudah dalam penyampaian dan meningkatkan pemahaman siswa terhadap wabah covid 19.

Adapun tujuan yang ingin dicapai dari pelaksanaan kegiatan ini adalah:

1. Untuk meningkatkan kualitas pembelajaran dan profesionalisme pendidik.

2. Untuk menghindari kejenuhan dalam kegiatan belajar siswa di rumah

3. Meningkatkan kesadaran hidup bersih, kesadaran cinta lingkungan, agar terhindar dari wabah covid 19.

4. Untuk mempermudah mencapai tujuan pembelajaran.

Adapun langkah-langkah yang dilakukan dalam pengerjaan proyek ini adalah:

1. Berembuk bersama semua guru khususnya yang mengajar di kelas 8 , untuk mencari kompetensi dasar yang sesuai dengan mata pelajaran lain, dan digabungkan dalam satu tema. Dari hasil rembungan tersebut kami berhasil menggabungkan 11 mata pelajaran dalam satu kegiatan pengerjaan proyek, tema yang diambil dihubungkan dengan masalah yang sedang dihadapi oleh kita sekarang ini yaitu Covid 19 dan kita pun mencarikan solusi agar bisa keluar dari wabah ini, akhirnya dari hasil diskusi kami ambil tema Merdeka Dari Covid 19.

2. Langkah kedua. Karena kita tidak bisa berkomunikasi langsung dengan siswa, maka untuk memperjelas tujuan pemlajaran kita komunikasikan juga dengan orang tua siswa, baik via daring ataupun luring. Kegiatan penyampaian tujuan kegiatan pembelajaran kepada orang tua siswa ini perlu dilakukan, untuk memberikan pemahaman bahwa pembelajaran yang akan dilakukan memerlukan kolaborasi antar guru, siswa dan orang tua. Orang tua siswa mempunyai tugas untuk membimbing putra-putrinya belajar selama kegiatan berlangsung, dengan tetap bisa melakukan aktivitas sebagai mana mestinya. Pihak sekolah juga memahani tidak semua orang tua bisa membimbing anak-anaknya secara penuh karena ada juga orang tua siswa yang harus bekerja mencari nafkah, selain itu juga kami memahami tidak semua orang tua siswa paham dengan materi pelajaran yang akan diberikan kepada siswa. Akan tetapi bimbingan mutlak diperlukan, minimalnya orang tua siswa tahu proyek apa dan materi apa yang akan sisampaikan oleh guru dalam kegiatan pembelajaran, lalu juga dalam pertemuan ini dibahas media komunikasi yang akan digunakan dalam 
kegiatan pembalajaran jarak jauh, untuk mempermudah ketercapaian Pembelajaran Jarak jauh. Dari hasil diskusi yang dilakukan di sepakati kalau media yang digunakan adalah WA group kelas.

3. Menjelaskan manfaat melakukan pembelajaran berbasis proyek selain pada orang tua siswa juga pada siswa. Adapun tujuan yang ingin dicapai adalah: membuat siswa aktif dan kreatif, sehingga proses kegiatan belajar tidak hanya terpaku pada lembar kerja atau layar handphone yang terkadang membuat jenuh, dengan membuat Proyek diharapkan menjadi cara yang bagus untuk membuat anak terlibat dalam pembelajaran otentik dan membangun keterampilan yang bermanfaat. Guru juga dapat menjelaskan bahwa proyek merupakan peluang yang baik bagi keluarga, untuk melakukan berbagai hal bersama dan sebaliknya proyek juga dapat membuat anak mandiri.

4. Menjelaskan cara mendukung anak-anak mereka yaitu dengan memberikan pemahaman kepada orangtua bahwa setiap anak mempunyai gaya yang berbeda dalam belajar, dan yang utama kita harus tenangkan kalau kegiatan pembelajaran jarak jauh ini jangan menjadikan stres, belajar harus dengan bahagia sehingga siswa tidak terbebami dengan kegiatan pembelajaran jarak jauh. Sekarang ini kita sudah terbebani dengan wabah covid 19 ini, jangan sampai pembelajaran jarak jauh menambah beban siswa dan orang tua siswa. Sebagai pendidik kita juga tidak menuntut siswa untuk sempurna, akan tetapi yang terpenting adalah semua sehat dan selamat dari wabah covid 19 ini, akan tetapi potensi siswa tetap tergali dan tujuan pembelajaran dapat tercapai maksimal. Orang tua siswa boleh menghubungi guru kapanpun jika ada hal hal yang tidak dipahami.

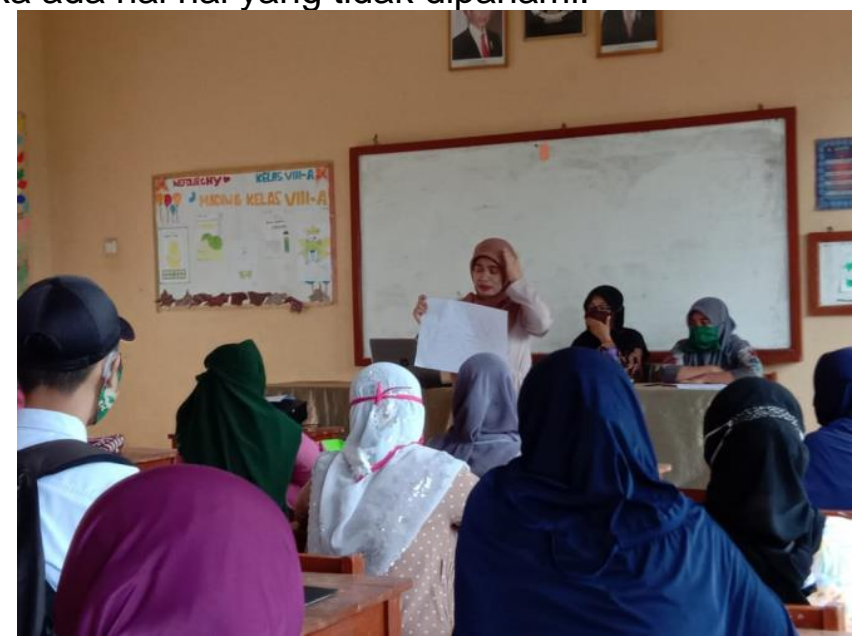

Gambar 1. Poto kegiatan pertemuan dengan orang tua siswa

Berdasarkan hasil pertemuan dan komunikasi dengan orang tua siswa kami sepakat kalau kegiatan pembelajaran dilakukan dengan media komunikasi lewat WA group, proyek disepakati selama 3 minggu dimulai dari minggu ke dua bulan Oktober sampai minggu terakhir bulan Oktober tahun 2020, guru memberikan pembelajaran melalui WA group dengan memberikan bahan ajar materi yang akan dipelajari siswa, selain itu juga untuk lebih memperjelas materi guru juga mengirimkan vidio singkat, yang sebelumnya sudah disiapkan oleh semua guru mata pelajaran untuk mempermudah siswa dalam pengerjaan proyek. Setiap hari orang tua siswa menyampaikan perkembangan belajar putra-putirnya kepada guru, juga kesehatan putra putrinya. Guru membimbing dan memantau perkembangan proyek yang dibuat oleh siswa.

Adapun ke 11 mata pelajaran yang terlibat dalam kegiatan pembuatan proyek ini adalah: 
1. Kesenian, dengan materi yang diberikan membuat satu gambar virus corona diberi warna yang indah dan menarik.

2. Bahasa Sunda, dengan materi hakikat berita dan teks isi berita (isi berita yang dibahas dihubungkan dengan berita covid 19 sekarang ini)

3. Matematika, dengan materi yang dibahas, pola bilangan dihubungkan dengan data perkembangan covid 19, dari berita yang disampaikan oleh mata pelajaran bahasa sunda.

4. PKN, dengan materi yang dibahas Peraturan Perundang Undangan dalam sisten hukum nasional, materi yang dibahas dihubungkan dengan peraturan pemerintah yang berhubungan dengan covid 19.

5. IPS, dengan materi yang dibahas hubungan kebijakan PSBB dan dampaknya bagi mobilitas sosial yang terjadi sekarang ini

6. Prakarya, dengan materi pemampatan limbah dari kain sisa untuk membuat masker dalam rangka melindungi diri dari covid 19

7. Bahasa Indonseia, dengan materi Iklan layanan masrakat dan poster, materi dihubungkan dengan pencegahan, penularan dan penyembuhan covid 19

8. Bahasa Inggris, dengan materi memberi imbauan aturan dan keharusan, dihubungkan dengan imbauan, aturan dan keharusan yang dilakukan selama covid 19

9. IPA, dengan materi nutrisi sehat untuk meningkatkan sistem imunitas

10. PJOK dengan materi gerak sederhana untuk meningkatkan sistem imunitas tubuh

11. PAl dengan materi Sholat sunat yang dibahas tentang sholat shunat hajat memohon agar virus covid 19 cepat berlalu dan do'a keselamatan supaya terhindar dari wabah covid 19.
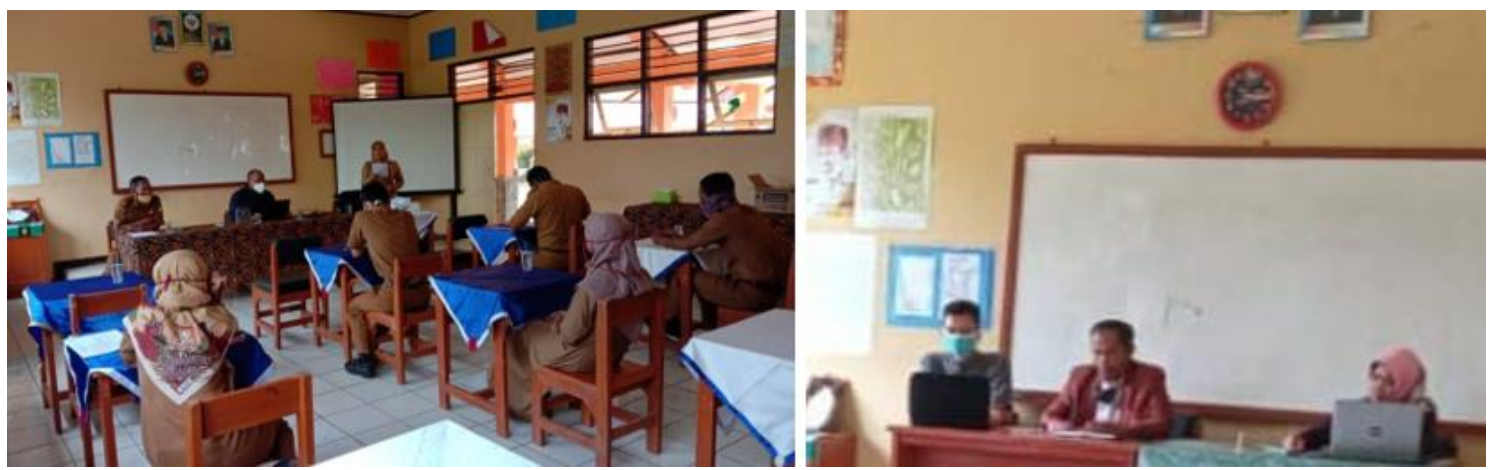

Gambar 2. Foto Evaluasi Kegitan PJJ Bersama Kepala Sekolah Dan Pengawas

Untuk memperjelas materi yang disampaikan oleh guru, kita juga membuat modul untuk dibagikan ke siswa baik melalui WA untuk yang daring dan yang tak bisa daring kita berikan foto kopinya dan diambil ke sekolah, akan tetapi jika ada yang memerlukan walau bisa komunikasi lewat daring modul bisa diambil ke sekolah dengan jam yang sudah diatur oleh pihak sekolah sebelumnya. Modul berisi tentang bahan ajar, ringkasan materi dan juga lembar tugas yang yang harus dikerjakan. Selain membuat modul guru juga membuat vidio pembelajaran berdurasi singkat antara 3 sampai 5 menit.

Untuk memudahkan kegiatan pembelajaran kami mengubah jadwal kegiatan Pembelajaran Jarak Jauh menjadi lebih sederhana mempermudah siswa untuk mengikuti kegiatan belajar. Penilaian yang dilakukan adalah penilaian proses, dimana penilaian dilakukan sebelum, ketika dalam kegiatan pembelajaran dan penilai akhir. Namun yang ditekankan adalah penilaian proses yaitu ketika siswa melakukan kegiatan pembelajaran di rumah. Kegiatan penilaian proses dilakukan dilihat dari kegiatan vidio atau poto yang dikirimkan ke group WA sekolah. 
Setelah diamati dari hari kehari tampak kegiatan pembelajaran yang dilakukan oleh siswa, dan untuk memotivasi siswa dalam belajar, dihari yang tidak ditentukan dipilih siswa yang paling aktif dan paling awal mengirimkan kegiatan belaja, kemudian diberikan hadiah. Hadiah sederhana tapi bisa memotivasi belajar siswa. Pengambilan hadiah oleh orang tua siswa ke sekolah dengan jadwal yang sudah ditentukan.

Pada minggu ke tiga diambil 15 besar terbaik, kemudian kami buatkan vidio gabungan dengan tematik untuk menggabungkan antara mata pelajaran yang satu dengan mata pelajaran yang lainnya, dalam satu kesatuan yang utuh, hasil presentasi siswa secara keseluruhan kami simpan ke youtube, sebagai bukti fisik hasil kegiatan pembelajaran dan juga untuk memotivasi siswa yang lainnya dalam kegiatan pembelajaran, juga sebagai pemberian informasi dari pencegahan, penularan dan pengobatan covid 19. Adapun link yang bisa diakses sebagai hasul kegiatan pembelajaran merdeka Dari Covid 19 adalah https://www.youtube.com/watch?v=be9RzS6ZgPA

Dari kegiatan-kegiatan yang dilakukan di atas, selah dianalisis hasilnya sebagai berikut:

1. Dengan keterlibatan seluruh guru mata pelajaran, walikelas dan juga orang tua siswa dalam kegiatan pembelajaran jarak jauh ssebagai satu kesatuan, dengan tema yang diangkat Merdeka dari Covid 19 membuat tujuan pembelajaran mudah tercapai. Anak-anak aktif dalam mengerjaan tugas yang diberikan oleh guru. Pehamanan anak-anak tentang covid 19 juga meningkat, ini dapat terlihat dari hasil penilaian yang dilakukan dari kegiatan belajar yang dilakukan. Ini dibuktikan dari hasil penilaian yang dilakukan oleh semua guru mata pelajaran.

2. Nilai pengetahuan, keterampilan dan Sikap, selama proses kegiatan pembelajaran juga meningkat akan tetapi kami tidak mengejar target capaian kurikulum, tapi alhamdulillah dari hari kehari terlihat motivasi belajar anak-anak semakin meningkat.

3. Dari ketepatan waktu siswa mengumpulkan tugas, 96 persen siswa mengerjakan tugas dengan tepat waktu. Tugas akhir selain diberikan lewat group WA dengan cara dipotokan, juga diberikan oleh orang tua siswa ke sekolah, dengan jadwal yang telah ditentukan dan sesuai dengan protokol kesehatan Covid 19.

4. Dari hasil survey yang dilakukan, lewat link gogleform, $96 \%$ siswa menjawab menjadi tahu tentang gejala, penularan, dan pencegahan covid 19.

5. Dari hasil survey yang dilakukan lewat link gogleform, $94 \%$ siswa merasa senang dengan kegiatan pembelajaran yang dilakukan.
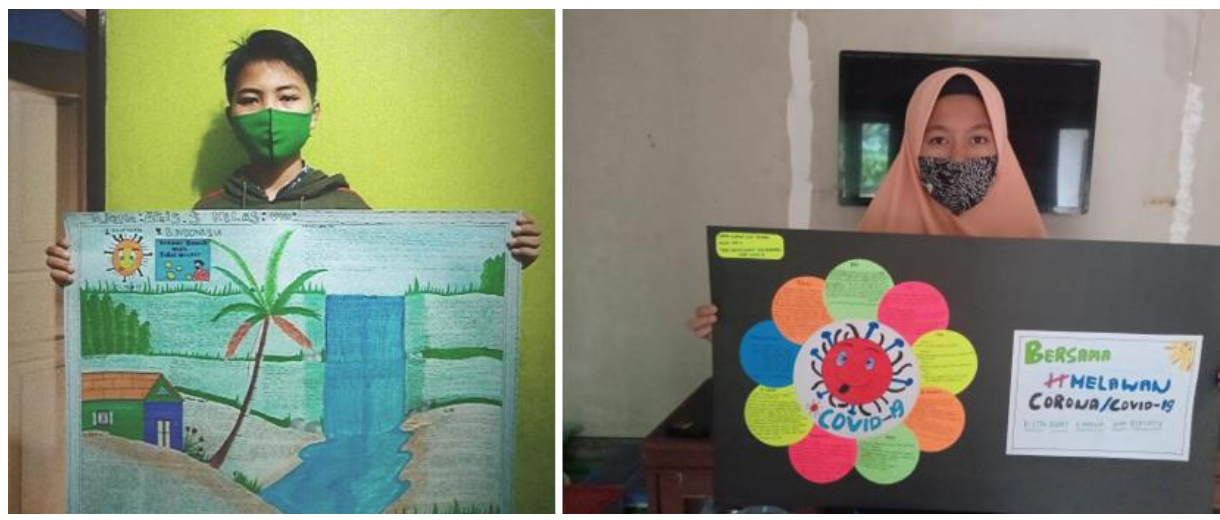

Gambar 3. Hasil Belajar Siswa Selama Di Rumah

Itulah salah satu hasil kegiatan PJJ yang sudah dilakukan di SMPN 4 Cikalongwetan, yang telah kami terapkan setelah sebelumnya kami juga melakukan 
kolaborasi dengan 9 mata pelajaran untuk kelas 9, dengan tema Inspirasi Dari Kupu Kupu Sebagai Motivasi Hidup Untuk terus berjuang

Pembelajaran jarak jauh yang tadinya terasa sulit akhirnya bisa dilakukan dengan penuh rasa bahagia, Pembelajaran yang dilakukan dengan rasa bahagia akan menghasilkan suatu karya yang bermakna, bukankah pada dasarnya manusia harus bahagia, guru bahagia, siswa bahagia, orang tua bahagia dan pendidikan seharusnya menggembirakan semua agar lebih menghasilkan generasi penerus yang lebih berkualitas di kemudian hari..

\section{SIMPULAN}

Dari hasil kegiatan yang dilakukan, dapat diambil kesimpulan bahwa pembelajaran jarak jauh dengan menggunakan model pembelajaran Project Based Learning dengan kolaborai 11 mata pelajaran dan juga bekersama dengan orang tua siswa di kelas 8 SMP Negeri 4 Cikalongwetan, yang mengangkat tema Merdeka dari covid 19, dapat meningkatkan pemahaman siswa terhadap wabah covid 19, selain itu juga mempercepat penyampaian pesan akan bahaya wabah covid 19 kepada siswa dan juga orang tua siswa. Untuk kedepannya, alangkah baiknya jika guru dan orang tua melakukan kolaborasi dalam melakukan kegiatan pembelajaran, selain itu juga guru harus terus melakukan inovasi dalam kegiatan pembelajaran, supaya kegiatan pembelajaran dapat mencapai tujuan yang sudah ditentukan dan juga kegiatan pembelajaran tidak menjenuhkan.

\section{DAFTAR PUSTAKA}

https://carapandang.com/read-news/7-tips-mengajar-dari-mendikbud-di-masapandemi-covid19

https://pgsd.binus.ac.id/2018/11/23/pentingnya-pembelajaran-bermakna-meaningfulllearning/

http://jurnal.unpad.ac.id/jkk/article/view/23620

Abdullah Sani, Ridwan. 2014. Pembelajaran Saintifik untuk Implementasi Kurikulum 2013. Jakarta: PT. Bumi Aksara

Agustina, Iko. 2014. Pengaruh Strategi Pembelajaran Berbasis Proyek terhadap Kemampuan Menulis Proposal Kegiatan Siswa Kelas XI SMA Negeri 2 Sidikalang T. P 2013/2014. Medan: UNIMED 